\title{
Effects of salinity and ontogenetic movements on strontium:calcium ratios in the otoliths of the Japanese eel, Anguilla japonica Temminck and Schlegel
}

\author{
Wann-Nian Tzeng \\ Department of Zoology, College of Science, National Taiwan University, Taipei, 10617, Taiwan, ROC
}

Received 6 June 1995; revised 27 November 1995; accepted 28 November 1995

\begin{abstract}
To study the mechanism of Sr incorporation into otoliths of the Japanese eel, Anguilla japonica, a total of 100 elvers collected from an estuary were reared in the laboratory at salinities of 0,10 , 25 and 35\% for approximately seven months. The elvers grew from $56 \mathrm{~mm}$ TL to $100-300 \mathrm{~mm}$ TL. Twenty elvers were randomly selected and the $\mathrm{Ca}$ and $\mathrm{Sr}$ concentrations of their otoliths were analyzed from the primordium to the edge, using an electron microprobe equipped with a four-channel wavelength-dispersive spectrometer. $\mathrm{Sr} / \mathrm{Ca}$ ratios in the otoliths of eels reared in various salinities were much lower than the ratio of $15 \times 10^{-3}$ observed in elvers about one month before they arrived at the estuary. The irreversibility of $\mathrm{Sr} / \mathrm{Ca}$ ratios at $35 \%$ salinity in this experiment indicated that the drastic change of the Sr/Ca ratios in otoliths of elvers was not due to the reduction of salinity in the coastal waters, but more likely to the development from leptocephalus to glass eel. The mean $\mathrm{Sr} / \mathrm{Ca}$ ratios in the new increments of the otoliths of eels during the rearing period were highly correlated with salinity $(S),[\mathrm{Sr} / \mathrm{Ca}] \times 10^{3}=3.797+0.14 S$ $(n=20, r=0.77$ ), which can be used to predict elver movements and habitat utilization rates.
\end{abstract}

Keywords: Japanese eel; Otolith; Migration; Strontium; Salinity; Development stage

\section{Introduction}

As in other teleost fishes, the otoliths of eels are composed of calcium carbonate in the crystal form of aragonite (Carlstrom, 1963; Degens et al., 1969; Morales-Nin, 1987; Lecomte-Finiger, 1992) and are deposited daily in alternating protein-rich and carbonate-rich layers as the fish grows (Pannella, 1971; Campana and Neilson, 1985; Lee and Lee, 1989; Tsukamoto, 1989). This variable deposition enables the daily age of the fish to be determined and their growth history to be studied (Tabeta et al., 1987; Tsukamoto, 
1989, 1990; Tzeng, 1990; Jones, 1992; Tzeng and Tsai, 1992). In the formation of aragonite crystal a few trace elements co-precipitate with calcium carbonate (Gunn et al., 1992; Ophel and Judd, 1967; Rosenthal, 1956, 1963; Smith et al., 1979; Toole and Nielsen, 1992). Sr is one of the most common elements to replace $\mathrm{Ca}$ because it has a similar ionic radius and valence (Amiel et al., 1973). Recently, Sr/Ca ratios in otoliths, in relation to ambient temperature and together with daily ages, have been used to reconstruct the past environmental histories of fishes (Radtke et al., 1990; Townsend et al., 1992). Because sea water contains more Sr than freshwater (Tzeng and Tsai, 1994), the change in the $\mathrm{Sr} / \mathrm{Ca}$ ratios in otoliths has also been used to study the migratory history of diadromous fishes such as American and European eels (Casselman, 1982), Hawaiian gobies (Radtke et al., 1988), salmonids (Kalish, 1990) and striped bass (Secor, 1992) in their movements between sea water and freshwater environments. These studies indicated that $\mathrm{Sr} / \mathrm{Ca}$ ratios in otoliths have the potential for retrieving the past environmental history of the fish. However, the incorporation of $\mathrm{Sr}$ in otoliths is a complicated biogeochemical process influenced by environmental factors and physiological conditions, and $\mathrm{Sr} / \mathrm{Ca}$ ratios as environmental predictors in fishes have only rarely been experimentally validated (Kalish, 1989, 1991; Gallahar and Kingsford, 1992; Radtke and Shafer, 1992; Sadovy and Severin, 1992).

The Japanese eel, Anguilla japonica Temminck and Schlegel, is a catadromous fish. Its life cycle is similar to the European eel, Anguilla anguilla, and includes five stages: leptocephalus, glass eel, elver, yellow eel and silver eel (Bertin, 1956). The Japanese eel spawns in the waters west of Mariana Island (Tsukamoto, 1992) and the leptocephalus larvae drift with the North Equatorial Current and Kuroshio Current (Kimura et al., 1994). As they approach the continental shelf, leptocephali metamorphose into glass eels and leave the Kuroshio for coastal waters (Tsukamoto and Umezawa, 1994). The glass eels become elvers in the estuaries (Bertin, 1956). During this long journey, the eels experience a salinity gradient from oceanic to coastal waters and a developmental transition from leptocephali to glass eels. Otolith microchemistry analyses indicate that the $\mathrm{Sr} / \mathrm{Ca}$ ratios in otoliths of elvers change drastically during their migration from spawning ground to the river estuary (Otake et al., 1994; Tzeng and Tsai, 1994). It has been suggested that this drastic change in $\mathrm{Sr} / \mathrm{Ca}$ ratios in otoliths is the result of the metamorphosis of the leptocephalus to a glass eel, or the result of a reduction of salinity in coastal waters (Otake et al., 1994; Tzeng and Tsai, 1994).

This study attempted to elucidate the factors affecting the $\mathrm{Sr} / \mathrm{Ca}$ ratios in otoliths of the Japanese eel during its migration from ocean to river by examination of $\mathrm{Sr}$ and $\mathrm{Ca}$ concentration in the otoliths of elvers reared in waters of various salinity and to determine the reliability of $\mathrm{Sr} / \mathrm{Ca}$ ratios as an environmental indicator for wild eels.

\section{Materials and methods}

Due to difficulty in collection of leptocephali and keeping them alive, elvers collected from the Tanshui River estuary in northern Taiwan on 8th March 1992 were used for the study. The elvers were at pigmentation stage VA with no pigment except caudal spots (Strubberg, 1913; Bertin, 1956). Their total lengths (TL) ranged from $52.2 \mathrm{~mm}$ to 58.9 
Table 1

Mean ( \pm S.D.) total length and otolith diameter of the eels reared from elvers for 7 months in growth chambers at temperatures of $22-23^{\circ} \mathrm{C}$ and $27-28^{\circ} \mathrm{C}$ and salinities of $0,10,25$ and $35 \%$

\begin{tabular}{lllclr}
\hline Treatment & $\begin{array}{l}\text { Temperature } \\
\left({ }^{\circ} \mathrm{C}\right)\end{array}$ & $\begin{array}{l}\text { Salinity } \\
(\%)\end{array}$ & No. fish survived & $\begin{array}{l}\text { Total length } \\
(\mathrm{mm})\end{array}$ & \multicolumn{1}{l}{$\begin{array}{l}\text { Otolith diameter } \\
(\mu \mathrm{m})\end{array}$} \\
\hline 1 & 28 & 35 & 10 & $143.45 \pm 23.39$ & $851.67 \pm 112.48$ \\
2 & 28 & 25 & 10 & $163.60 \pm 28.52$ & $961.63 \pm 138.82$ \\
3 & 28 & 10 & 9 & $184.11 \pm 35.04$ & $1000.10 \pm 184.62$ \\
4 & 28 & 0 & 10 & $164.95 \pm 27.87$ & $945.69 \pm 125.86$ \\
5 & 28 & 0 & 6 & $184.67 \pm 58.19$ & $990.52 \pm 213.78$ \\
6 & 23 & 35 & 10 & $126.75 \pm 29.22$ & $761.24 \pm 119.99$ \\
7 & 23 & 25 & 9 & $129.33 \pm 21.30$ & $765.55 \pm 96.49$ \\
8 & 23 & 10 & 10 & $144.90 \pm 23.98$ & $820.36 \pm 104.34$ \\
9 & 23 & 0 & 10 & $145.65 \pm 20.52$ & $805.69 \pm 97.10$ \\
10 & 23 & 35 & 9 & $148.44 \pm 28.87$ & $832.11 \pm 141.95$ \\
\hline
\end{tabular}

The stocking density is $11^{-1}$ except the treatments of Nos. 5 and 10 which were 0.51

"Temperature during daytime. Night temperature is $1^{\circ} \mathrm{C}$ lower.

$\mathrm{mm}$ with a mean of $55.3 \mathrm{~mm}$. After an acclimation period of 2 days in brackish water of salinity $11.57 \%$ under natural photoperiod, 100 randomly selected elvers were divided into ten treatment groups, each containing ten eels and reared in growth chambers at two temperature regimes of $22-23^{\circ} \mathrm{C}$ and $27-28^{\circ} \mathrm{C}$ and salinities of $0,10,25$ and $35 \%$. The stocking density was one fish $\mathrm{I}^{-1}$ except treatment Nos. 5 and 10 where the density was $0.51^{-1}$ (Table 1). The temperature and salinity were set by referring to those where the leptocephali and glass eels were sampled (Kimura et al., 1994; Otake et al., 1994; Tzeng and Tsai, 1994). The salinities of the rearing water were prepared from an approximately $32 \%$ natural sea water adjusted with tap water and crude salt (dried natural sea salt obtained from Tainan table-salt processing plant). The fish were fed to satiation once a day with formulated larval eel food supplemented with live tubifex worms. Faeces were siphoned daily and the rearing water was changed at intervals of approximately 2 weeks. The water level was maintained constant by adding water periodically. The $\mathrm{Sr}$ and $\mathrm{Ca}$ concentrations and salinity of the rearing water (Table 2) were measured with an atomic absorption spectrophotometry (Perkin-Elmer 703) and salinometer (WTW microprocessor conductivity meter LF196), respectively.

The eels were reared for approximately 7 months and the experiment ended on 12 October 1992. The surviving eels were sacrificed, their total lengths were measured to

Table 2

Relationship between strontium $(\mathrm{Sr})$ and calcium (Ca) contents, $\mathrm{Sr} / \mathrm{Ca}$ ratios and the salinity of the rearing water

\begin{tabular}{lllc}
\hline Salinity $(\%)$ & $\mathrm{Sr}(\mathrm{ppm})$ & $\mathrm{Ca}(\mathrm{ppm})$ & $\mathrm{Sr} / \mathrm{Ca}\left(\times 10^{-2}\right)$ \\
\hline 0 & 0.17 & 27.67 & 6.14 \\
10 & 1.9 & 181.0 & 10.50 \\
25 & 3.95 & 314.5 & 12.56 \\
35 & 5.4 & 471.67 & 11.45 \\
\hline
\end{tabular}


nearest $0.01 \mathrm{~mm}$ with calipers and they were weighed to $0.01 \mathrm{~g}$ with an electronic balance. Sagittal otoliths were removed 1 week after fixation in $95 \%$ alcohol.

The maximum diameter of each of the otoliths was measured with a computer-aided image processing system (VIPRO 512) and the otoliths were then embedded in resin. The procedures for embedding, polishing and ctching of the otolith for $\mathrm{Sr}$ and $\mathrm{Ca}$ content measurements followed those described by Tzeng (1990) and Tzeng and Tsai (1992, 1994). The $\mathrm{Sr}$ and $\mathrm{Ca}$ contents in otoliths of the 20 randomly selected eels were analyzed using an electron microprobe equipped with a four-channel wavelength dispersive spectrometer (WDS; Shimadzu-ARL EMX-SM). In the analyses of Sr and $\mathrm{Ca}, \mathrm{SrTiO}_{3}$ and $\mathrm{CaSO}_{4}$ were used as standards. The weight percentage composition of $\mathrm{CaSO}_{4}$ equals $41.19 \% \mathrm{CaO}$ plus $58.81 \% \mathrm{SO}_{3}$ and $\mathrm{SrTiO}_{3}$ equals $56.46 \%$ SrO plus $43.54 \% \mathrm{TiO}_{2}$. The electron beam was focused on an area approximately $5 \mu \mathrm{m}$ in diameter at intervals of approximately $20 \mu \mathrm{m}$ along the frontal scction of the otolith maximum radius from primordium to edge. The accelerating voltage of electron was 15 $\mathrm{kV}$ with specimen current of $0.01 \mu \mathrm{A}$. The counts for spectrometers of the elements were evaluated using five $4 \mathrm{~s}$ integration periods and at the wavelengths of $3.3685 \AA$ ( $\mathrm{Ca}-\mathrm{Ka})$ and $6.8628 \AA$ ( $\mathrm{Sr}-\mathrm{La})$, respectively. In the ZAF correction procedures (Chen and Tung, 1984), the weight percentages of $\mathrm{SrO}$ and $\mathrm{CaO}$ in otolith were calculated using a constant of $\mathrm{CO}_{2}$ at $43.97 \%$. The relative contents of $\mathrm{Sr}$ and $\mathrm{Ca}$ in a percentage of otolith weight were then estimated.

In order to establish the positions of the primordium, elver checks and microprobe spots on the otoliths before and after the WDS analysis, each otolith was photographed with transmitted and reflected light under a light microscope (Fig. 1a, b). The otolith was then etched with 5\% EDTA (ethylene diamine tetra-acetate; $\mathrm{pH}$ adjusted with $\mathrm{NaOH}$ to 7.4) and photographed with transmitted light to reconfirm the primordium and elver checks (Fig. 1c) and to discriminate the leptocephalus metamorphosis check from the transition of otolith microstructures and $\mathrm{Sr} / \mathrm{Ca}$ ratios (Otake et al., 1994; Tzeng and Tsai, 1994). With the aid of the microphotographs, the distances from the primordium to each of the microprobe spots and the checks were measured precisely. The Sr/Ca ratios in the new increments of otolith, which encompassed the rearing period were then examined.

The differences between treatments for fish growth and otolith $\mathrm{Sr} / \mathrm{Ca}$ ratios were examined using an analysis of variance (ANOVA). A forward stepwise regression analysis was used to test the relationships between otolith $\mathrm{Sr} / \mathrm{Ca}$ ratios and temperature, salinity, ambient $\mathrm{Sr} / \mathrm{Ca}$ ratios, fish length and weight and otolith diameter. The significance of differences in otolith $\mathrm{Sr} / \mathrm{Ca}$ ratios between salinities was further tested by Scheffe's multiple range analysis (Sokal and Rohlf, 1969).

\section{Results}

\subsection{Growth}

After 7 months of rearing, 93 eels had survived. The elvers grew from approximately $56 \mathrm{~mm}$ TL to $100-300 \mathrm{~mm}$ TL. Mortality rates of elvers did not differ among treatment groups $(P>0.05)$. The somatic and otolith growth rates were significantly different 

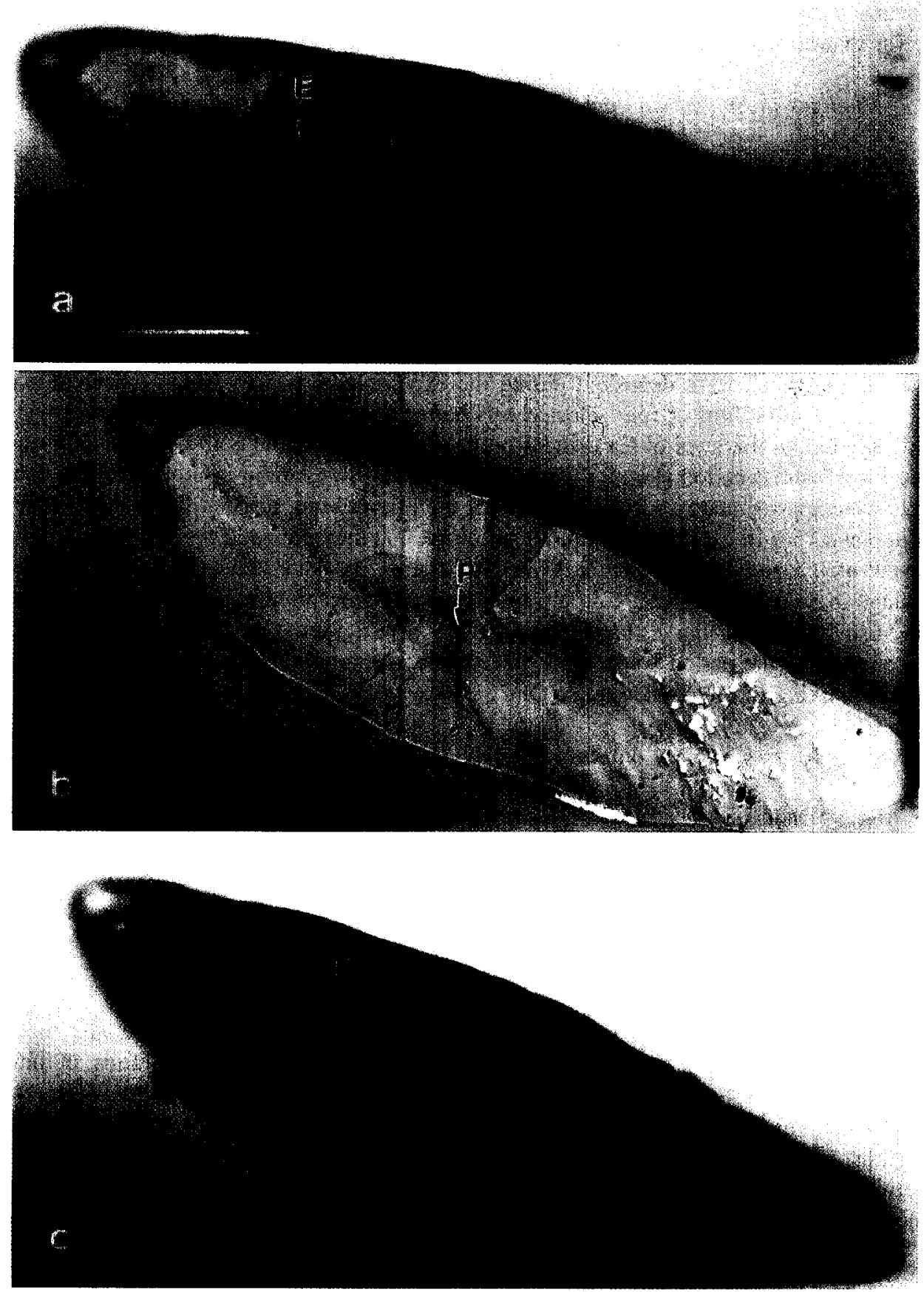

Fig. 1. Microphotographs of the otolith from a $162 \mathrm{~mm}$ TL eel showing (a, c): primordium (P); leptocephalus metamorphosis check (M); elver check (E) and (b) 17 microprobe spots. Scale bar $=150 \mu \mathrm{m}$. Photos a, b and c were taken for different purposes, as described in the text. 
between different temperatures $(P<0.01)$, salinities $(P<0.05)$ and rearing densities $(P<0.05)$ and there was no interaction among these three treatments $(P>0.05)$. Both mean somatic and otolith growth rates were greater at $27-28^{\circ} \mathrm{C}$ than at $22-23^{\circ} \mathrm{C}$, at lower than at higher salinities and at lower than at higher rearing densities (Table 1 ).

\subsection{Changes in $\mathrm{Sr}$ and $\mathrm{Ca}$ contents and $\mathrm{Sr} / \mathrm{Ca}$ ratios in otoliths during development}

The otolith of a $162 \mathrm{~mm}$ TL eel reared from $56 \mathrm{~mm}$ TL at the salinity $10 \%$ and the temperature $27-28^{\circ} \mathrm{C}$ shows both leptocephalus metamorphosis and elver checks at approximately $89 \mu \mathrm{m}$ and $145 \mu \mathrm{m}$ from the primordium, respectively, which were discernible from the change of microstructural pattern of their growth increments (Fig. 1). The elver check was deposited when the glass eel arrived at the estuary (Tzeng and Tsai, 1994; Tzeng et al., 1994) and provides a convenient way to distinguish otolith increments deposited before and during the experimental period. The new increments outside the check were deposited during the experimental period. Both Sr content and $\mathrm{Sr} / \mathrm{Ca}$ ratio in otoliths of four selected eels before the experimental period show a wide fluctuation; but the level of $\mathrm{Ca}$ content in the otoliths was stable both before and during the experimental period (Fig. 2). The $\mathrm{Sr}$ content and $\mathrm{Sr} / \mathrm{Ca}$ ratio in otoliths of the four eels were approximately 0.3 and $8 \times 10^{-3}$ at the primordium, reached the highest values of 0.6 and $15 \times 10^{-3}$ at the metamorphosis check and then dramatically decreased to low levels of 0.3 and $8 \times 10^{-3}$ at the elver check (Fig. 2). This indicated that the drastic change in $\mathrm{Sr}$ content and $\mathrm{Sr} / \mathrm{Ca}$ ratio in elver otoliths occurred about one month before the fish arrived at the estuary. The highest $\mathrm{Sr} / \mathrm{Ca}$ ratios in the otoliths probably correspond to the period when the leptocephalus metamorphosed to the glass eel stage before moving into coastal waters (Otake et al., 1994; Tzeng and Tsai, 1994).

\subsection{Effects of salinity on otolith $\mathrm{Sr} / \mathrm{Ca}$ ratios}

ANOVA indicated that $\mathrm{Sr} / \mathrm{Ca}$ ratios in new increments of the otolith deposited during the experimental period were not significantly different between temperatures $(P>0.5)$. They were, however, significantly different between salinities $(P<0.01)$ but there were no interactions between temperature and salinity $(P>0.9)$. Forward stepwise regression analysis also indicated that of the six variables temperature, salinity, ambient $\mathrm{Sr} / \mathrm{Ca}$ ratio, fish length and weight and otolith diameter, only salinity influenced the $\mathrm{Sr} / \mathrm{Ca}$ ratios in otoliths.

The relationship between otolith $\mathrm{Sr} / \mathrm{Ca}$ ratio and salinity $(S)$ was estimated to be $[\mathrm{Sr} / \mathrm{Ca}] \times 10^{3}=3.797+0.14 S(n=20, r=0.77)$ (Fig. 3). Mcan $\mathrm{Sr} / \mathrm{Ca}$ ratios in new increments of otoliths increased significantly from $4.20 \times 10^{-3}$ in the freshwater to $9.27 \times 10^{-3}$ at $35 \%$ salinity (Table 3) and this result indicated that $\mathrm{Sr} / \mathrm{Ca}$ ratios in otoliths could be used as an environmental indicator for studying the migration of eels between freshwater and sea water. On the other hand, the $\mathrm{Sr} / \mathrm{Ca}$ ratios of the new increments in otoliths of eels reared at the various salinities and both $22-23^{\circ} \mathrm{C}$ and $27-28^{\circ} \mathrm{C}$ were much lower than the highest value of $15 \times 10^{-3}$ in the otoliths of the elvers 1 month before they arrived at the estuary (Figs. 2,3, Table 3). The irreversibility of $\mathrm{Sr} / \mathrm{Ca}$ ratios in otolith of the eel at the salinity of $35 \%$ in the rearing experiment indicated that the drastic change of the $\mathrm{Sr} / \mathrm{Ca}$ ratios in otoliths of elvers may be not due 

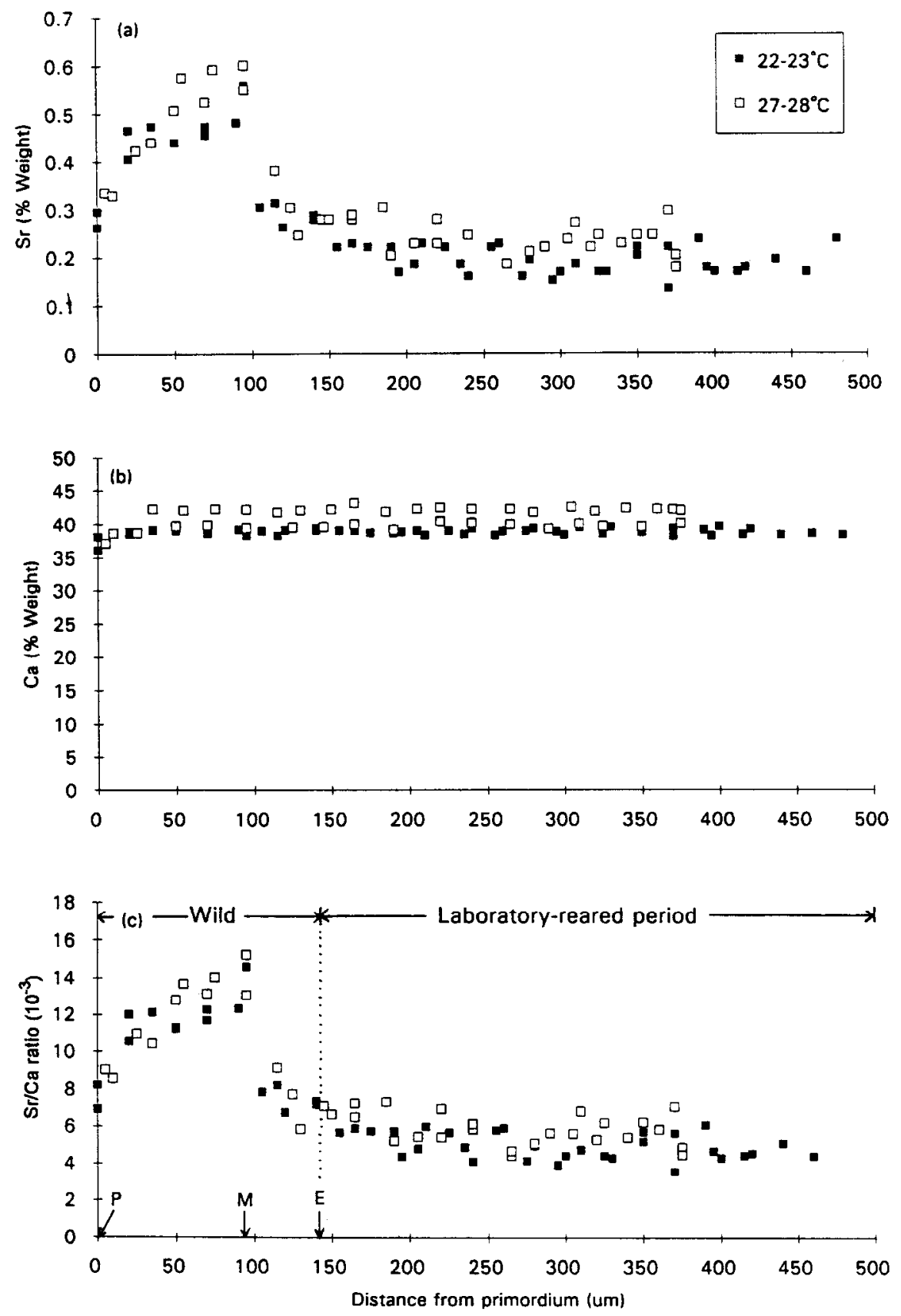

Fig. 2. Changes in $\mathrm{Sr}$ (a), $\mathrm{Ca}$ (b) contents and $\mathrm{Sr} / \mathrm{Ca}$ ratios (c) in otoliths during development. $\mathrm{Sr}$ and $\mathrm{Ca}$ contents were measured from the primordium to the edge of the otoliths of four selected eels (143, 162,165 and $173 \mathrm{~mm}$ in total length) reared from elvers at $10 \%$ salinity and two temperature regimes of $22-23^{\circ} \mathrm{C}$ and $27-28^{\circ} \mathrm{C}$. F, denotes the mean position of elver check; $M$, leptocephalus metamorphosis check and $P$, primordium. 


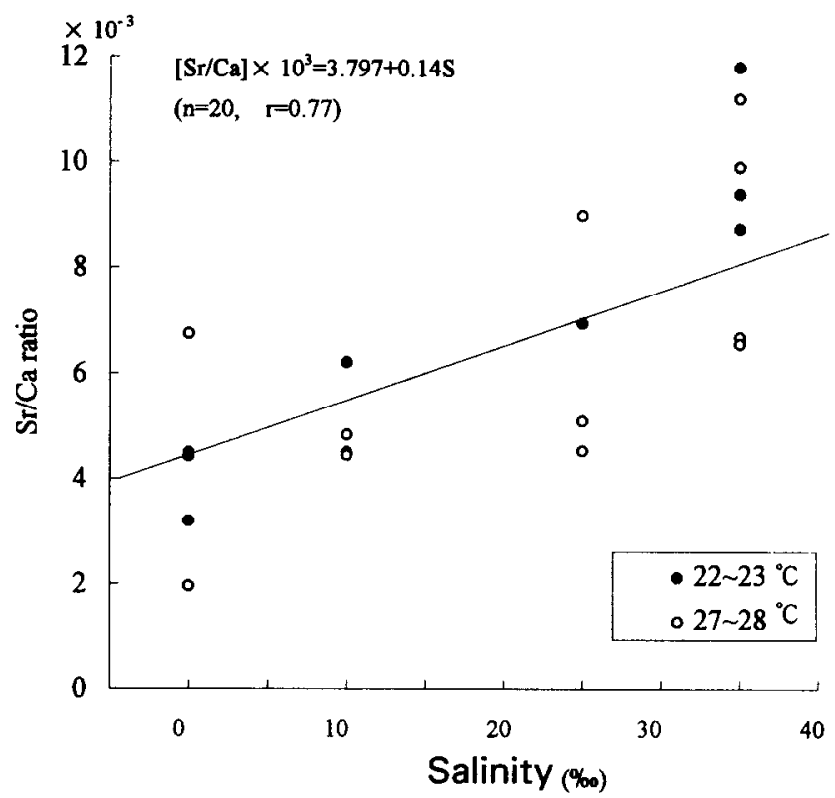

Fig. 3. Relationship between otolith $\mathrm{Sr} / \mathrm{Ca}$ ratio and salinity.

to the reduction of salinity in the coastal waters, but more likely to the transition from leptocephalus to glass eel.

\section{Discussion and conclusions}

The relationship between $\mathrm{Sr} / \mathrm{Ca}$ ratios in the otoliths of reared eels and ambient salinity (Fig. 3) is consistent with the change of $\mathrm{Sr} / \mathrm{Ca}$ ratios in otoliths of the wild eels that experience changes in salinity during their migration from the estuary to the river (Tzeng and Tsai, 1994). These data also validate the use of $\mathrm{Sr} / \mathrm{Ca}$ ratios in otoliths as environmental indicators to reconstruct the migratory history of the eel between freshwater and sea water. This change in Sr/Ca ratios in otolith has also been found in other diadromous fishes e.g., American and European eels (Casselman, 1982), salmonids (Kalish, 1990), Hawaiian gobies (Radtke et al., 1988) and striped bass (Secor, 1992)

Table 3

Scheffe's multiple range analysis of mean $\mathrm{Sr} / \mathrm{Ca}$ ratios in new increments of the otoliths of the Japanese eel rcarcd in different salinities. Groups of salinities sharing the same column of asterisks are homogeneous

\begin{tabular}{llll}
\hline Salinity $(\% \circ)$ & Sample size & Sr/Ca ratio $\left(\times 10^{-3}\right)$ & Homogeneous group \\
\hline 0 & 5 & 4.20 & $*$ \\
10 & 4 & 4.99 & $*$ \\
25 & 4 & 6.57 & $* *$ \\
35 & 7 & 9.27 & $*$ \\
\hline
\end{tabular}


during their migration between freshwater and sea water. These results indicate that the relationship between $\mathrm{Sr} / \mathrm{Ca}$ ratios in fish otoliths and ambient salinity may be an universal rule in diadromous fishes.

Incorporation of $\mathrm{Sr}$ into otoliths is a complicated biogeochemical process influenced by physical factors such as temperature, salinity and water chemistry, as well as by biological factors such as genetics, developmental stage, growth rate, food and physiological condition of the fish (Dodd, 1967; Gallahar and Kingsford, 1992; Kalish, 1989; Radtke and Shafer, 1992; Sadovy and Severin, 1992; Yamada et al., 1979). The $\mathrm{Sr} / \mathrm{Ca}$ ratios in otoliths of elvers drastically decreased from a high value of $15 \times 10^{-3}$ to a low level of approximately $8 \times 10^{-3}$ about 1 month before the fish arrived at the estuary (Fig. 2). It was suggested that this decrease corresponded to the period when the leptocephali metamorphose to glass eels and leave the warm Kuroshio Current for cold coastal waters (Otake et al., 1994; Tzeng and Tsai, 1994). During this period, salinity, temperature and the change in developmental stage may all have the potential to influence the $\mathrm{Sr} / \mathrm{Ca}$ ratios of the otoliths.

The experimental eels were exposed to temperatures of $27-28^{\circ} \mathrm{C}$ and a salinity of $35 \%$, which were very close to the $27.0-29.0^{\circ} \mathrm{C}$ and $34.5-34.7 \%$ of the natural waters where the leptocephali were collected (Otake et al., 1994). The mean $\mathrm{Sr} / \mathrm{Ca}$ ratios in the new increments of otoliths of the eels reared in 35\% sea water (Fig. 3 and Table 3 ) were much lower than the highest value of $15 \times 10^{-3}$ observed in otoliths of elvers before the experimental period (Fig. 2). The temperature and salinity in the natural environment gradually decrease during the elver migration from the Kuroshio area to coastal waters. It has been reported elsewhere that the $\mathrm{Sr} / \mathrm{Ca}$ ratio in the otolith is inversely related to ambient temperature (Radtke et al., 1990; Townsend et al., 1992, 1995; Tzeng, 1994). Hence if the change in the $\mathrm{Sr} / \mathrm{Ca}$ ratios in otoliths of elvers is due to temperature, the $\mathrm{Sr} / \mathrm{Ca}$ ratios in the otoliths from metamorphosis to elver check (Fig. 2) should increase but not decrease because during this period the fish migrate toward a low temperature. On the other hand, if the change in $\mathrm{Sr} / \mathrm{Ca}$ ratios in otoliths of elvers resulted from the salinity gradient, when the salinity of the rearing water was elevated to the salinity of $35 \%$, the $\mathrm{Sr} / \mathrm{Ca}$ ratios in otoliths of the eel during the experimental period should increase to the highest value observed in the otoliths of elvers before the experimental period. This was not the case in the present study. Therefore, temperature and salinity are probably not the primary factors determining the drastic change of $\mathrm{Sr} / \mathrm{Ca}$ ratios in otoliths of elvers during their migration from the open ocean to the river. An alternative possibility is the saltatory developmental change from leptocephalus to glass eel.

Until now, the leptocephali of Japanese eel or other species of Genus Anguilla have only rarely been collected and no experiments have been done to validate the mechanism of $\mathrm{Sr}$ incorporation in otoliths at the time of metamorphosis. Strontium metabolism in the leptocephalus stage has been considered to be different from that in the elver stage (Hulet, 1978; Keys and Willmer, 1932; Ophel and Judd, 1967; Utida and Hirano, 1973). The leptocephalus is known to contain extensive amounts of gelatinous extracellular matrix composed of sulfated glycosaminoglycans (GAGs) which are broken down during metamorphosis (Pfeiler, 1984, 1986). Since GAGs have an affinity for alkali earth elements, particularly $\mathrm{Sr}^{2+}$ (Comper and Laurent, 1978; Nishizawa, 1978; Hascall and IIascall, 1981; Toole, 1981), GAGs breakdown may reduce the absorption of $\mathrm{Sr}^{2+}$ 
from sea water and result in a drastic decrease in otolith Sr content and, consequently, in $\mathrm{Sr} / \mathrm{Ca}$ ratio (Otake et al., 1994). In this study, $\mathrm{Sr} / \mathrm{Ca}$ ratios in otoliths of elvers increased gradually from the primordium, reached a peak prior to the metamorphosis check and then dropped suddenly thereafter (Fig. 2). Apparently, the drastic change of $\mathrm{Sr} / \mathrm{Ca}$ ratios in elver otoliths corresponds closcly to the metamorphosis from leptocephalus to glass eel.

In conclusion, the drastic change of the $\mathrm{Sr} / \mathrm{Ca}$ ratios in otoliths of elvers is most likely due to the transition from leptocephalus to glass eel. Otolith $\mathrm{Sr} / \mathrm{Ca}$ ratios at the elver stage are directly related to the ambient salinity and they can be used to predict elver movements and habitat utilization rates.

\section{Acknowledgments}

This study was financially supported by the National Science Foundation, Republic of China (Project NSC 82-0211-B002-044). The author expresses his gratitude to Miss H.F. Wu, Mr. Y.T. Wang, Miss C.H. Wang, Miss C.E. Wu and other colleagues at the laboratory of Fisheries Biology, Department of Zoology, National Taiwan University (NTU) for their assistance in the laboratory, to Dr. C.H. Chen, Department of Geology, NTU for assistance on WDS microprobe analysis and to Dr. C.F. Tsai and the anonymous referees for reviewing the manuscript.

\section{References}

Amiel, A.J., G.M. Friedman and D.S. Miller, 1973. Distribution and nature of incorporation of trace elements in modern aragonite corals. Sedimentology, Vol. 20, pp. 47-64.

Bertin, L., 1956. Eels - a biological study. Cleaver-Hume Press, London, 192 pp.

Campana, S.E. and J.D. Neilson, 1985. Microstructure of fish otoliths. Can. J. Fish. Aquat. Sci., Vol. 42, pp. 1014-1032.

Carlstrom, D., 1963. A crystallographic study of vertebrate otoliths. Biol. Bull, Vol. 25, pp. 441-463.

Casselman, J.M., 1982. Chemical analyses of the optically different zones in eel otoliths. In, Proceedings of the 1980 North American Eel Conference, edited by K.H. Loftus. Ont. Minist. Nat. Resour., Ont. Fish. Tech. Rep. Ser. 4, pp. 74-82.

Chen, C.H. and T.C. Tung, 1984. On-line data reduction for electron microprobe analysis. Acta Geol. Taiwan, Vol. 22, pp. 196-200.

Comper, W.D. and T.C. Laurent, 1978. Physiological function of connective tissue polysaccharides. Physiol. Rev., Vol. 58, pp. 255-315.

Degens, E.T., W.G. Deuser and R.L. Haedrich, 1969. Molecular structure and composition of fish otoliths. Mar. Biol, Vol. 2, pp. 105-113.

Dodd, R.J., 1967. Magnesium and strontium in calcareous skeletons: a review. J. Palaeontol., Vol. 41, pp. 1313-1329.

Gallahar, N.K. and M.J. Kingsford, 1992. Patterns of increment width and strontium:calcium ratios in otoliths of juvenile rock blackfish, Girella elevata (M.). J. Fish Biol., Vol. 41, pp. 749-763.

Gunn, J.S., I.R. Harrowfield, C.H. Proctor and R.E. Thresher, 1992. Electron probe microanalysis of fish otoliths: evaluation of techniques for studying age and stock discrimination. J. Exp. Mar. Biol. Ecol., Vol. 158., pp. 1-31. 
Hascall, V.C. and G.K. Hascall, 1981. Proteoglycans. In, Cell biology of extracellular matrix, edited by E.D. Hay. Plenum Press, New York, pp. 39-63.

Hulet, W.H., 1978. Structure and functional development of the eel leptocephalus Ariosoma balearicum (De La Roche, 1809). Phil. Trans. R. Soc. Lond. (Ser. B), Vol. 282, pp. 107-138.

Jones, C.M., 1992. Development and application of the otolith increment technique. In, Otolith microstructure examination and analysis, edited by D.K. Stevenson and S.E. Campana. Can. Spec. Publ. Fish. Aquat. Sci., Vol. 117, pp. 1-11.

Kalish, J.M., 1989. Otolith microchemistry: validation of the effects of physiology, age and environment on otolith composition. J. Exp. Mar. Biol. Ecol., Vol. 132, pp. 151178.

Kalish, J.M, 1990. Use of otolith microchemistry to distinguish the progeny of sympatric anadromous and non-anadromous salmonids. U.S. Fish. Bull., Vol. 88, pp. 657-666.

Kalish. J.M., 1991. Determinants of otolith chemistry: seasonal variation in composition of blond plasma, endolymph and otolith of bearded rock cod Pseudophysis barbatus. Mar. Ecol. Prog. Ser., Vol. 74, pp. $137-159$.

Keys, A.B. and E.N. Willmer, 1932. Chloride secreting cells in the gills of fishes, with special reference to the common eel. J. Physiol. Lond., Vol. 76, pp. 368-378.

Kimura, S., K. Tsukamoto and T. Sugimoto, 1994. A model for the larval migration of the Japanese eel: roles of the trade winds and a salinity front. Mar. Biol., Vol. 119, pp. 185-190.

Lecomte-Finiger, R., 1992. Growth history and age at recruitment of European glass eels (Anguilla anguilla) as revealed by otolith microstructure. Mar. Biol., Vol. 114, pp. 205-210.

Lee, T.W. and K.S. Lee, 1989. Daily growth increments and lunar pattern in otolith of the eel, Anguilla japonica, in freshwater. Bull. Korea Fish Soc., Vol. 22, pp. 36-40.

Morales-Nin, B., 1987. Ultrastructure of the organic and inorganic constituents of the otoliths of the sea bass. In, Age and growth of fish, edited by R.C. Summerfelt and G.E. Hall, Iowa State University Press, Ames, IA, pp. $331 \cdot 343$.

Nishizawa, K., 1978. Marine algae from a viewpoint of pharmaceutical studies. Jap. J. Phycol., Vol. 26. 73-78.

Ophel. I.L. and J.M. Judd, 1967. Skeletal distribution of strontium and calcium and strontium/calcium ratios in various species of fish. In, Strontium Metabolism, edited by J.M.A. Lenihan, J.F. Loutit and J.H. Martin. Academic Press, London, pp. 101-109.

Otake, T., T. Ishii, M. Nakahara and R. Nakamura, 1994. Drastic changes in otolith strontium/calcium ratios in leptocephali and glass eels of Japanese eel Anguilla japonica. Mar. Ecol. Prog. Ser., Vol. 113, pp. 189-193.

Pannella, G., 1971. Fish otoliths: daily growth layers and periodical patterns. Science, Vol. 173, pp. 1124-1127.

Pfeiler, E., 1984. Glycosaminoglycan breakdown during metamorphosis of larval bonefish Albula. Mar. Biol. Lett., Vol. 5, pp. 241-249.

Pfeiler, E., 1986. Towards an explanation of the developmental strategy in leptocephalus larvae of marine teleost fishes. Environ. Biol. Fish, Vol. 15, pp. 3-13.

Radtke, R.L., R.A. Kinzie III and S.D. Folsom, 1988. Age at recruitment of Hawaiian freshwater gobies Environ. Biol. Fish., Vol. 23, pp. 205-213.

Radtke, R.L., D.W. Townsend, S.D. Folsom and M.A. Morrison, 1990. Strontium: Calcium ratios in larval herring otoliths as indicators of environmental histories. Environ. Biol. Fish., Vol. 27, pp. 51-61.

Radtke, R.I. and D.I. Shafer, 1992. Fnvironmental sensitivity of fish otolith microchemistry. Aust. J. Mar. Freshwater Res., Vol. 43, pp. 935-951.

Rosenthal, H.L., 1956. Uptake of $\mathrm{Ca}^{45}$ and $\mathrm{Sr}^{911}$ from water by freshwater fishes. Science, Vol. 126, pp. $699-700$.

Rosenthal, H.L., 1963. Uptake, turnover and transport of bone seeking elements in fishes. Ann. N.Y. Acad. Sci., Vol. 109, pp. 278-293.

Sadovy, Y. and K.P. Severin, 1992. Trace elements in biogenic aragonite: correlation of body growth rate and strontium levels in the otoliths of the white grunt, Haemulon plumieri (Pisces: Haemulidae). Bull. Mar. Sci., Vol. 50, pp. 237-257.

Secor, D.H., 1992. Application of otolith microchemistry analysis to investigate anadromy in Chesapeake Bay striped bass Morone saxatilis. U.S. Fish. Bull., Vol. 90, pp. 798-806. 
Smith, S.V., R.W. Buddemeier, R.C. Redalje and J.E. Houck, 1979. Strontium-calcium thermometry in coral skeletons. Science, Vol. 204, pp. 404-406.

Sokal, R.R. and F.J. Rohlf, 1969. Biometry. W.H. Freeman, San Francisco, CA.

Strubberg. A.C., 1913. The metamorphosis of elvers as influenced by outward conditions. Meddr. Kommn. Havunders. Ser. Fisk., Vol. 4, pp. 1-11.

Tabeta, O., K. Tanaka, J. Yamada and W.N. Tzeng, 1987. Aspects of the early life history of tle Japantese eel Anguilla japonica determined from otolith microstructure. Nippon Suisan Gakkaishi, Vol. 53, pp. 17271734.

Toole, B.P., 1981. Glycosaminoglycans in morphogenesis. In, Cell Biology of Extracellular Matrix, edited by E.D. Hay. Plenum Press, New York, pp. 259-294.

Toole, C.L. and R.L. Nielsen, 1992. Effects of microprobe precision of hypotheses related to otolith $\mathrm{Sr} / \mathrm{Ca}$ ratios. U.S. Fish. Bull., Vol. 90, pp. 421-427.

Townsend, D.W., R.L. Radtke, S. Corwin and A.L. David, 1992. Strontium: calcium ratios in juvenile Atlantic herring Clupea harengus L. otolith as a function of water temperature. J. Exp. Mar. Biol. Ecol., Vol. 160, pp. $131-140$.

Townsend, D.W., R.L. Radtke, D.P. Malone and J.P. Wallinga, 1995. Use of otolith strontium:calcium ratios for hindcasting larval cod Gadus morhua distributions relative to water masses on Georges Bank. Mar. Ecol. Prog. Ser., Vol. 119, pp. 37-44.

Tsukamoto, K., 1989. Otolith daily growth increments in the Japanese eel. Nippon Suisan Gakkaishi, Vol. 55, pp. $1017-1021$.

Tsukamoto, K., 1990. Recruitment mechanism of the eel, Anguilla japonica to the Japanese coast. J. Fish Biol., Vol. 36, pp. 659-671.

Tsukamoto, K., 1992. Discovery of the spawning area for Japanese eel. Nature, Vol. 356, pp. 789-791.

Tsukamoto, K. and A. Umezawa, 1994. Metamorphosis: a key factor of larval migration determining geographic distribution and speciation of eels. In, Proceedings of 4th Indo Pacific fish conference, Bangkok, Thailand, 28 Nov.-4 Dec. 1993. pp. 231-248.

Tzeng, W.N., 1990. Relationship between growth rate and age at recruitment of Anguilla japonica elvers in a Taiwan estuary as inferred from otolith growth increments. Mar. Biol., Vol. 107, pp. 75-81.

Tzeng, W.N., 1994. Temperature effects on the incorporation of strontium in otolith of Japanese eel, Anguilla japonica Termminck and Schlegel. J. Fish Biol., Vol. 45, pp. 1055-1066.

Tzeng, W.N. and Y.C. Tsai, 1992. Otolith microstructure and daily age of Anguilla japonica elvers from the estuaries of Taiwan with reference to unit stock and larval migration. J. Fish Biol., Vol. 40, pp. 845-857.

Tzeng, W.N., H.F. Wu and H. Wickström, 1994. Scanning electron microscopic analysis of annulus microstructure in otolith of European eel, Anguilla anguilla. J. Fish Biol., Vol. 45, pp. 479-492.

Tzeng, W.N. and Y.C. Tsai, 1994. Changes in otolith microchemistry of the Japanese eel, Anguilla japonica, during its migration from the ocean to the rivers of Taiwan. J. Fish Biol., Vol. 45, pp. 671-684.

Utida, S. and T. Hirano, 1973. Effects of changes in environmental salinity on salt and water movement in the intestine and gills of the eel, Anguilla japonica. In, Responses of fish to environmental changes, edited by W. Chavin. Thomas, Springfield, pp. 240-269.

Yamada, S.B., T.J. Mulligan and S.J. Fairchild, 1979. Strontium marking of hatchery reared coho salmon (Oncorhynchus kisutch, Walbaum). J. Fish Biol., Vol. 14, pp. 267-275. 